\title{
Usefulness of Network Analysis to Characterize Technology Leaders in Small Dual-Purpose Cattle Farms in Mexico
}

\author{
Oriana Villarroel-Molina ${ }^{1}\left(\mathbb{D}\right.$, Carmen De-Pablos-Heredero ${ }^{2, * \mathbb{D}}$, Jaime Rangel ${ }^{3}$, María Prosperina Vitale 4 \\ and Antón García ${ }^{1}$ (D)
}

1 Animal Science Department, Rabanales University Campus, University of Cordoba, 14071 Cordoba, Spain; z42vimoo@uco.es (O.V.-M.); pa1gamaa@uco.es (A.G.)

2 Department of Business Economics (Administration, Management and Organization), Applied Economics II and Fundamentals of Economic Analysis, ESIC Business \& Marketing School, Rey Juan Carlos University, Paseo de los Artilleros s/n, 28032 Madrid, Spain

3 Mexico's National Institute for Forestry, Agriculture and Livestock Research (INIFAP), Medellín de Bravo 94277, Mexico; rangel.jaime@inifap.gob.mx

4 Department of Political and Social Studies, University of Salerno, Via Giovanni Paolo II 132, IT 84084 Fiscano, Italy; mvitale@unisa.it

* Correspondence: carmen.depablos@urjc.es

Citation: Villarroel-Molina, O.; De-Pablos-Heredero, C.; Rangel, J.; Vitale, M.P.; García, A. Usefulness of Network Analysis to Characterize Technology Leaders in Small Dual-Purpose Cattle Farms in Mexico. Sustainability 2021, 13, 2291.

https://doi.org/10.3390/su13042291

Academic Editor: Roswitha Baumung

Received: 28 January 2021

Accepted: 17 February 2021

Published: 20 February 2021

Publisher's Note: MDPI stays neutral with regard to jurisdictional claims in published maps and institutional affiliations.

Copyright: (c) 2021 by the authors. Licensee MDPI, Basel, Switzerland. This article is an open access article distributed under the terms and conditions of the Creative Commons Attribution (CC BY) license (https:// creativecommons.org/licenses/by/ $4.0 /)$.

\begin{abstract}
The low technology adoption rate is one of the major problems in very small dual-purpose cattle farms in Mexico. Using the social network analysis approach, we characterized the farmer leaders in the innovation network and deepened the knowledge on the low technological adoption causes. The sample consisted of 383 very small farms of dual-purpose cattle characterized by using nine reproductive management technologies. Our findings suggested that the network position of farmers had a significant impact on the technological level. Hence, the farmers farthest from the technology leaders showed the lowest levels of betweenness centrality index and high rates of constraint. Apart from this, advice, productive orientation, and intensification were also differentiating elements at the technological level. The findings provided relevant insights and useful tools to policy makers to better support, coordinate and enhance the adoption of innovation among smallholders.
\end{abstract}

Keywords: social network analysis; innovations; dual-purpose cattle; technology adoption; centrality network indices

\section{Introduction}

Smallholder livestock production constitutes a major component of developing countries' economies, a contribution that goes beyond direct food production to include multipurpose uses, such as food supply, source of income, assets saving, source of employment, soil fertility, livelihood, transport, agricultural traction and sustainable production [1,2]. Nevertheless, the significance of smallholder agriculture is not only limited to a subgroup of low-income countries, contrary to widespread perception. Smallholder also plays an essential role in the EU and OECD countries, where they are an alternative to large and specialised farms; especially in the aftermath of the economic and financial crisis [3]. However, this does not mean that the problems faced by smallholders are identical in all these countries. Neither does it mean that the role of smallholder agriculture in broader processes of development is the same everywhere [4,5].

In Mexico, dual-purpose cattle encompasses between $51-67 \%$ of the highly marginalized area's producers [6,7], contributing to the maintenance of traditional ways of life in the agricultural sector, and generating direct income [8-10]. The dual-purpose productive system is an alternative to increasing profitability in livestock. From the biological point of view, this system favours the increase in cow dairy potential by crossing meat breeds adapted with specialized dairy breeds but conserving the rusticity of these animals [11,12]. Therefore, this is a traditional and extensive grazing system that uses low-cost resources, 
contributing to mitigate climate change by reducing greenhouse gas (GHG) emissions and increasing carbon accumulation $[11,13,14]$.

The low technology adoption rate is one of the major problems of very small dualpurpose farms in Mexico [9,11,12,15]. According to Rangel et al. [13], these farmers use only $46.96 \%$ of the technologies potentially available to them. In this sense, EspinosaGarcía et al. [14] have pointed out that this is compounded by the lack of technology transfer programmes and technical assistance. Even when the adoption of new agricultural technologies is an important route out of poverty for many in the developing world, agricultural innovations are often adopted slowly, and some aspects of the adoption process remain poorly understood $[5,15-18]$. This indicates a need to investigate the reasons for the low technological adoption rate in dual-purpose livestock systems. With the purpose to understand the failures in the adoption process, previous studies have mainly focused on the farm's size and credit constraints on the adoption process $[7,19]$. However, very few empirical researchers have explored the relationships between a farmer's contact networks and his decision to adopt or reject new technologies, and how these interactions may work to enhance or limit smallholder farmer innovation $[18,20]$. Hence, a need to improve the understanding of technology adoption from a social network analysis (SNA) perspective [21-26] has been identified, with a focus on the relationships among key farmers capable of spreading innovation and enhancing the adoption of new technologies. The social network analysis approach is used to identify farmers who are performing well and are successful at what they do, to evaluate with a benchmark analysis the strengths and weaknesses of their technological practices and the steps needed to improve their performance. Regarding the usefulness of benchmarking analysis in the context of innovation dissemination, Kahan [27] stated that farmers often do benchmarking informally from something as straightforward as observing and talking to successful farmers. A farmer sees another farmer with a larger harvest or one who gets a better price for the same product at the same market. Why is this so? A farmer hears of another farmer who reduces costs by introducing a new technology. Should she or he do the same? This study is aimed to answer the following research questions:

What characterizes the key farmers in the technology adoption network? What are their technology strategies? Are the farmers playing a central position in the network the most innovative?

The objectives of this study were to identify influencer farmers in the innovation network and to perform a benchmarking analysis to evaluate what characteristics these leaders had, and thus deepen the knowledge of the rejection causes during technology adoption processes of dual-purpose cattle smallholders in Mexico.

\section{Materials and Methods}

\subsection{Data Collection}

This study was part of a larger research project in the Mexican tropics, where dualpurpose cattle farms were characterized according to their technological innovation level into five groups [11,28]. Data were collected from 2013 to 2016 by direct surveys done to smallholders of dual-purpose who have received technical advice from Mexico's Ministry of Agriculture, Livestock, Rural Development, Fisheries and Food (SAGARPA). Here, we focused on the more vulnerable and smaller group of farmers with 50 or fewer cows $(n=383)$, which represented $26 \%$ of the sample, distributed into dry and wet tropics. The main characteristics of this group were previously described in $[6,8,11,29]$.

\subsection{Livestock Innovation Level}

The selection of technological innovations was accomplished through qualitative and participatory analysis, according to the methodology described by Rangel et al. $[9,11,30,31]$, Torres et al. [9,11,30,31], and Rivas et al. [9,11,30,31], based on the farmer's technological preferences. Forty-five technologies were identified and grouped in five technological areas: management, feeding, reproduction, genetics and animal health, favouring a systemic 
and non-linear vision of innovation, within a transversal, collaborative and interactive process [29]. In this work, we focused on the area of reproductive management, as it is the one with the lowest technological level. This area is composed of nine technologies: using male breeds (T23), using male crosses (T24), using female breeds (T25), using female crosses (T26), use of genetically tested bulls (T27), calf selection criteria (T28), female selection criteria (T29), sire selection criteria (T30), and crossbred system (T31).

\subsection{Methodological Background}

In the current study, we used the SNA methodological perspective from the social capital theory as a core element in the access to technological resources embedded in livestock innovation networks [32-38]. Social capital consists of a series of resources that individuals can obtain from the structure of social networks. Two of the most important resources are information flowing through networks and obligations of reciprocity, which can come out of the confidence between agents in the same network [32,39-41]. Therefore, SNA provides a useful theoretical framework to investigate social structures and has been recognised as a distinct research approach to study relations rather than attributes, mapping trust and knowledge networks [28,35], and therefore can be applied to the study of social capital [36,38,42].

In this study, social capital is considered to be a resource through which farmers access valuable information that allows them to be more efficient in the production process. It is believed that those farmers well connected to key players (technological leaders) can imitate their strategies, which becomes a competitive advantage. Hence, it is not necessarily true that the farmers with a higher rate of technological adoption are the most productive, but rather a group of farmers appear on the network that, making use of this advantage in access to information, manage themselves to be more efficient with fewer technologies [23]. These technologies are known as core technologies, with a high impact on productivity. Consequently, the position of a certain farmer and their proximity to the technological leaders in the technological innovation network is crucial when adopting or rejecting technology [23]. Then, social networks as a form of social capital constitute a production input which can affect the farmer's productive capabilities and their level of technological adoption, influencing the economic performance and explaining the differences of the adoption rate among farmers with similar endowments [5].

In recent years, there has been an increasing amount of literature supporting the idea of social capital as a competitive advantage, explaining economic outcomes on the individual level [34,39,43-45]. According to Webb [42], the interactions within community members who interact directly, frequently, in multi-faceted ways, generate opportunities by providing them with a competitive advantage in pursuing their ends. Burt [39] described social capital as a function of brokerage opportunities, while Rodríguez-Modroño [34] suggested it to be a source of information that enables the development of productive synergies. Similarly, Saint Ville et al. [37] studied how different forms of social capital may affect innovation in smallholder farming systems and they found a strong presence of interpersonal agricultural knowledge networks operating to: (1) facilitate farmer-to-farmer knowledge exchange; (2) increase farmer access to information; and (3) connect farmers to sources of support, pointing out the role of peer farmers as the primary source of new agricultural knowledge.

\subsection{Network Measures Definition}

The SNA methodology has developed a series of measures that are directly related to social capital and therefore are included in the processes of agricultural extension to foster innovation. According to Borgatti et al. [33,46], Bonacich [47-49], Opsahl [50], and Freeman [51], the network measures considered in the following analyses are:

Degree: Degree has a positive relation to social capital, since the more actors you have relationships with, the greater the chance that one of them has the resource you need. Closeness: Since closeness is related to the reciprocal of geodesic distance from an actor 
to all the others in the network, it has a negative relationship with social capital. So, the greater the distance to other actors, the less the chance of receiving information in a timely way. Betweenness: Actors with high betweenness link together actors who are otherwise unconnected, creating opportunities for the exploitation of information and control benefits, which makes the relation positive. Eigenvector: is the extent to which an actor is connected to actors who present themselves with high values of eigenvector centrality. Therefore, actors have high eigenvector scores when they are connected to well-connected others, making the relation to social capital positive. Constraint: Network constraint is an index that measures the extent to which an actor's contacts are redundant. Constraint is high if contacts are directly connected to one another (dense network) or indirectly connected via a central contact [39]. Therefore, the more constrained the actor, the fewer opportunities for action, which make the relationship between constraint and social capital negative.

\subsection{Network Definition and Benchmark}

Firstly, we constructed a two-mode network of 383 farmers and nine technologies based on the technological package of each respondent. Two-mode networks, also known as affiliation networks [52,53], consist of recording instances in which individuals participate in or attend the same events, or where there are archival data indicating which people belong to which organizations [54]. This type of network allowed us to identify technological adoption patterns, as well as those of the organization's membership. Secondly, after considering the different ways of analysing two-mode networks developed by Borgatti et al. $[52,53,55,56]$, Everett et al. $[52,53,55,56]$, and Hanneman $[52,53,55,56]$, the two-mode data were transformed into a bipartite graph. For the aim of this paper, the bipartite graph centrality measures were calculated, allowing the technological leaders to be identified.

In this case, we must note that the affiliation to an organization was considered as an essential and differentiating attribute. This is because it is believed that organizations are centres of social interaction and access to information, where communication flows, constituting a determining factor in the technology adoption processes. Therefore, through the surveys, it was possible to map six different types of organizations operating in the area, both public and private. The GGAVATT (Livestock Groups for Technological Validation and Transfer) was the most important organization at the public level, belonging to the Institute for Forestry, Agriculture and Livestock Research (INIFAP), an institution that operates nationally. The GGAVATT constituted the organization with the largest number of affiliated farmers (81.46\% of the sample). According to Ponce-Méndez et al. [57], the GGAVATT model is applicable at the regional and national level, to groups of livestock farmers with a common production goal and who were interested in adopting the technological model. The GGAVATT advisers made a holistic approach to the farm, considering the different areas of improvement (reproduction, feeding, management, health, quality, management and use of pastures).

In the private sector, there were several organizations. The second most important organization in the number of affiliates was the SPR (the Rural Production Society), with $9.4 \%$ of the sample. The Rural Production Society operates state-wide and was constituted by a group of producers who aim for agricultural activity improvement through the coordination of productive economic activities, mutual assistance, etc. This group of farmers also aims to obtain goods, services and public or private support to undertake, develop and consolidate productive and social investment projects. Other less widespread organizations in the area were the Cooperative Society $(3.66 \%)$, the producers' organization $(1.04 \%)$ and the non-productive organization $(2.09 \%)$. The results showed that a small group of farmers has no affiliation with any organization $(2.35 \%)$.

The farmers in the network were highlighted according to the organization type. The initial two-mode network was transformed into a one-mode network through UCINET software [58] for the network visualization and the identification of the influencer farmers (technological leaders) by considering their centrality network measures. Thus, only the 
farmers who have adopted six technologies or more are shown, that is, those with a technology adoption rate greater than $67 \%$.

Finally, a comparative benchmarking analysis was carried out among the profiles of seven dual-purpose farmers chosen through the SNA measures (degree, closeness, eigenvector, betweenness and constraint). The mean, median, standard deviation, coefficient of variation, minimum and maximum were the descriptive statistic used in the technological analyses. The approach is novel as it seeks to introduce network measures into the analysis to study how farmers make production decisions and what factors influence their decisions. The analysis and visualization of the dual-purpose cattle network in the Mexican tropics were carried out using the UCINET software [58].

\section{Results and Discussion}

\subsection{Descriptive Statistics}

The descriptive statistics of very small dual-purpose farms in Mexico are shown in Table 1. In this case, the highest variability was found in the cheese yield $(299.17 \%)$, due to the fact that not all farms produce cheese and dairy products. On the other hand, calves sold also showed high variability, with an average of 4.90 calves sold and a coefficient of variation of $118.56 \%$. These results showed the essence of this livestock system, which is obtaining milk and meat from the same animal and makes it evident that some farmers are mainly engaged in milk production and others in meat and milk joint production. This productive orientation will determine its technological strategy. Moreover, the average farm had 19.25 UA of herd size in 27.17 ha and 1.09 UA/ha of stocking rate. The farmer was 51 years old and three people were economically dependent on the farm (dependent relatives). The annual milk production was $11,229.4 \mathrm{~L}$ and the productivity per cow and ha was $988 \mathrm{~L} /$ cow and $108 \mathrm{~L} /$ ha, respectively.

Table 1. Structural characteristics of dual-purpose cattle farms $(n=383)$.

\begin{tabular}{|c|c|c|c|c|c|c|}
\hline Variables & Mean & Median & $\mathrm{SD}^{1}$ & $\mathrm{CV}^{2}$ & $\operatorname{Min}^{3}$ & $\operatorname{Max}^{4}$ \\
\hline Grazing surface, ha & 27.17 & 19 & 38.67 & $142.33 \%$ & 3 & 400 \\
\hline Total animal unit, UA & 19.25 & 19.2 & 3.96 & $20.57 \%$ & 10 & 47 \\
\hline Herd size, $\mathrm{n}^{\circ}$ cattle & 25.54 & 25 & 6.32 & $24.76 \%$ & 10 & 65 \\
\hline Stocking rate, UA/ha & 1.09 & 1 & 0.636 & $58.32 \%$ & 0.05 & 3.82 \\
\hline Milk production, 1 /year & 11,229 & 10,000 & 6825 & $60.78 \%$ & 0 & 36,500 \\
\hline Milk per cow, $1 /$ cow / year & 987.71 & 937.50 & 591.75 & $59.91 \%$ & 0 & 2940 \\
\hline Calves sold, $\mathrm{n}^{\circ}$ calves & 4.90 & 4 & 5.81 & $118.56 \%$ & 0 & 40 \\
\hline Unproductive animals, heads & 2.53 & 0 & 4.52 & $178.92 \%$ & 0 & 32 \\
\hline Cheese yield, kg/farm/year & 245.25 & 0 & 733.71 & $299.17 \%$ & 0 & 9000 \\
\hline Milk production, 1 /ha & 107.80 & 52.63 & 186.79 & $173.27 \%$ & 0 & 1429 \\
\hline Stakeholders age, years & 51 & 51 & 14.51 & $28.40 \%$ & 20 & 85 \\
\hline Dependents relatives, $n$ & 2.91 & 3 & 1.80 & $61.99 \%$ & 0 & 9 \\
\hline Employments, workers & 1.49 & 1 & 1.11 & $74.28 \%$ & 0 & 6 \\
\hline
\end{tabular}

${ }^{1}$ Standard deviation, ${ }^{2}$ Coefficient of variation, ${ }^{3}$ Minimum, ${ }^{4}$ Maximum.

Technology descriptive statistics are shown in Table 2. The reproductive management technologies had an average adoption rate of $59.18 \%$. However, the results showed that the crossbred system $(95.82 \%)$, sire selection criteria $(90.34 \%)$ and female selection criteria $(89.56 \%)$ are the most adopted technologies within this area, while female selection criteria $(89.56 \%)$, using female crosses $(71.28 \%)$ and using male crosses $(55.87 \%)$ have a medium level of adoption over the average. In contrast, calf selection criteria $(49.87 \%)$, using male breeds $(37.34 \%)$, using female breeds (22.45\%) and use of genetically tested bulls $(20.10 \%)$ are the least adopted technologies. 
Table 2. Reproductive management technologies in dual-purpose cattle farms.

\begin{tabular}{ccccc}
\hline Code & Technological Level (\%) & Mean & SD $^{\mathbf{1}}$ & CV $^{\mathbf{2}}$ \\
\hline T31 & Crossbred system & 95.82 & 0.200 & 4.01 \\
T30 & Sire selection criteria & 90.34 & 0.296 & 8.75 \\
T29 & Female selection criteria & 89.56 & 0.306 & 9.38 \\
T26 & Using female crosses & 71.28 & 0.453 & 20.53 \\
T24 & Using male crosses & 55.87 & 0.497 & 24.72 \\
T28 & Calves selection criteria & 49.87 & 0.501 & 25.07 \\
T23 & Using male breeds & 37.34 & 0.484 & 23.46 \\
T25 & Using female breeds & 22.45 & 0.418 & 17.46 \\
T27 & Use of genetically tested bulls & 20.10 & 0.401 & 16.10 \\
\hline
\end{tabular}

${ }^{1}$ Standard deviation, ${ }^{2}$ Coefficient of variation.

The descriptive statistics of the centrality network measures for the sample of 383 farmers (Table 3) showed that within the technological innovation network in reproductive management, dual-purpose farmers had an average degree of 5.38 with a minimum value of two and a maximum value of nine; the degree is related to the number of technologies that these farmers have adopted. The average betweenness was 3.92, being one of the measures with the highest coefficient of variation (8.93). These results were similar to that of Aguirre-López et al. [15], who found a betweenness of 0.394 in the adoption patterns of conservation agriculture practices among 222 maize smallholder farmers in the Mexican state of Chiapas. However, eigenvector and constraint showed the least variability, being 1.47 and 0.003 , respectively.

Table 3. Centrality network measures in dual-purpose cattle farms.

\begin{tabular}{cccccccc}
\hline & Mean & Standard Error & Median & SD $^{\mathbf{1}}$ & $\mathbf{C V}^{\mathbf{2}}$ & Min $^{\mathbf{3}}$ & $\mathbf{M a x}^{\mathbf{4}}$ \\
\hline Degree & 5.38 & 0.06 & 5 & 1.21 & 1.47 & 2 & 9 \\
Closeness & 793 & 0.283 & 793 & 5.52 & 30.45 & 785 & 839 \\
Eigenvector & 0.105 & 0.001 & 0.11 & 0.02 & 0.000 & 0.04 & 0.15 \\
Betweenness & 3.94 & 0.154 & 2.87 & 2.99 & 8.93 & 0.03 & 16.71 \\
Constraint & 0.198 & 0.003 & 0.20 & 0.06 & 0.003 & 0.11 & 0.50 \\
\hline
\end{tabular}

${ }^{1}$ Standard deviation, ${ }^{2}$ Coefficient of variation, ${ }^{3}$ Minimum, ${ }^{4}$ Maximum.

\subsection{Social Network Analysis Results}

The farmers grouped according to the type of organization are shown in Figure 1 (two-mode network). The GGAVATT farmers showed more homogeneous groups with well-defined structures, reluctant to technological exchange with other farmers external to their group. On the contrary, the SPR farmers were a smaller group, more heterogeneous and closer to the other associations. The GGAVATT and SPR farmers showed a higher level of technology adoption and a higher degree than the rest of the organizations (Table 4).

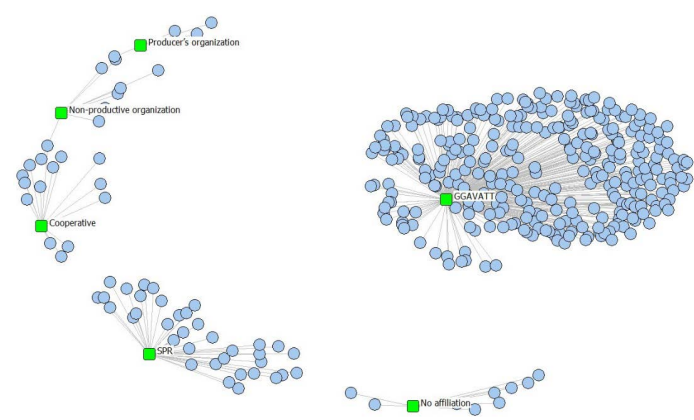

Figure 1. Two-mode network visualization of farmers and type of organization. $\square$ Organizations: GGAVATT (Livestock Groups for Technological Validation and Transfer), SPR (the Rural Production Society), cooperative, producer's organization, non-productive organization, no affiliation. Farmers. 
Table 4. Farmer's benchmarking by organization type.

\begin{tabular}{|c|c|c|c|c|c|c|c|}
\hline \multirow[b]{2}{*}{ Organization Type } & \multirow[b]{2}{*}{ Leader Farmer } & \multicolumn{2}{|c|}{ High Level } & \multicolumn{3}{|c|}{ Medium Level } & \multirow{2}{*}{$\begin{array}{c}\text { Low Level } \\
\begin{array}{c}\text { Non-Productive } \\
\text { Organization }\end{array}\end{array}$} \\
\hline & & GGAVATT $^{1}$ & $\mathrm{SPR}^{2}$ & Cooperative & $\begin{array}{l}\text { Producers } \\
\text { Organization }\end{array}$ & No Affiliation & \\
\hline Farmer, code & f_623 & f_374 & f_1165 & f_325 & f_522 & f_183 & f_76 \\
\hline \multicolumn{8}{|l|}{$\begin{array}{l}\text { Network Analysis } \\
\text { and technology }\end{array}$} \\
\hline $\begin{array}{c}\text { Technological } \\
\text { adoption rate, \% }\end{array}$ & 100 & 89 & 89 & 78 & 78 & 78 & 56 \\
\hline Degree & 9 & 8 & 8 & 7 & 7 & 7 & 5 \\
\hline Closeness & 785 & 787 & 787 & 789 & 789 & 789 & 793 \\
\hline Eigenvector & 0.15 & 0.13 & 0.13 & 0.12 & 0.12 & 0.13 & 0.11 \\
\hline Betweenness & 16.71 & 13.59 & 13.59 & 10.5 & 8.64 & 7.54 & 1.57 \\
\hline Constraint & 0.11 & 0.13 & 0.13 & 0.14 & 0.14 & 0.14 & 0.20 \\
\hline \multicolumn{8}{|l|}{ Structural characterization } \\
\hline Productive animals, cows & 11 & 13 & 14 & 11 & 17 & 10 & 11 \\
\hline Animal units, heads & 23.7 & 17.9 & 22.6 & 24.2 & 22.4 & 18.6 & 21.1 \\
\hline Stocking rate, UA/ha & 40 & 22 & 31 & 37 & 25 & 25 & 26 \\
\hline Grazing surface, ha & 1.00 & 1.12 & 2.26 & 0.56 & 1.32 & 0.81 & 0.41 \\
\hline Milk yield, 1/year & 20,020 & 11,040 & 24,000 & 15,330 & 18,250 & 12,600 & 7200 \\
\hline Milk per cow, $1 /$ cow / year & 1820 & 849 & 1714 & 1394 & 1074 & 1260 & 654 \\
\hline Calves sold, $\mathrm{n}^{\circ}$ calves & 13 & 0 & 10 & 5 & 0 & 3 & 0 \\
\hline $\begin{array}{l}\text { Cheese yield, } \\
\mathrm{kg} / \text { farm/year }\end{array}$ & 730 & 10 & 0 & 0 & 0 & 0 & 100 \\
\hline Stakeholders age, years & 50 & 28 & 40 & 64 & 45 & 48 & 52 \\
\hline Economics dependents, $\mathrm{n}^{\circ}$ & 1 & 1 & 3 & 8 & 5 & 1 & 3 \\
\hline Employees, workers & 4 & 1 & 1 & 3 & 4 & 3 & 3 \\
\hline
\end{tabular}

${ }^{1}$ Livestock Groups for Technological Validation and Transfer; ${ }^{2}$ the Rural Production Society. 
The dual-purpose farmer's network in reproductive management, coloured by organizations, are presented in Figure 2. In this innovation one-mode network, only one central farmer was found with the higher betweenness value and, therefore, with a very high social capital compared to their technological peers. This is the farmer $\mathrm{f}$ 623, affiliated to the SPR, the only farmer with an adoption rate of $100 \%$. The network structure highlighted that farmers affiliated to the GGAVATT tend to form homogenous groups. These results corroborate the findings of Rangel et al. [11], who found in the dual-purpose livestock system that while the structural characteristics of the farms were quite heterogeneous, the technological levels were quite homogeneous.

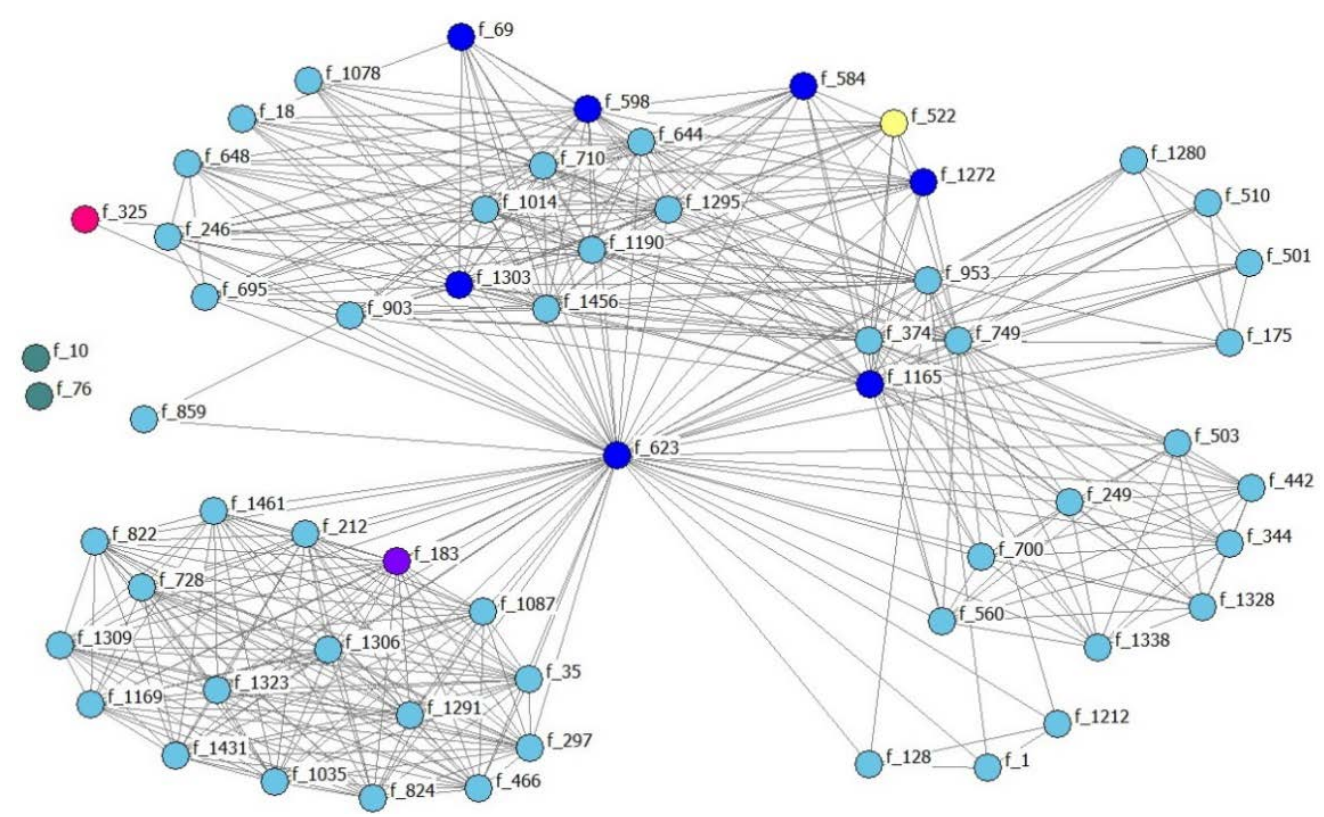

Figure 2. One-mode network visualization of farmers. Nodes' colour: organization type. Farmer code (f_n $\left.\mathrm{n}_{\mathrm{i}}\right)$, organization type: GAVVAT (Livestock Groups for Technological Validation and Transfer), $\bigcirc$ SPR (the Rural Production Society) cooperative, $\bigcirc$ producers organization, 1 no organization, $\bigcirc$ non-productive organization.

Figure 3 shows the two-mode network relating farmers and technologies. The network structure indicated that some of the reproductive management technologies were jointly adopted: calf selection criteria (T28), female selection criteria (T29) and sire selection criteria (T30). So, they were considered complementary technologies [11]. On the contrary, the technologies "male crosses" (T24) and "female crosses" (T26) followed another adoption pattern. These results also showed that the crossbred system (T31), with an adoption rate of $96 \%$, was the most widely adopted technology. It can be considered an elementary technology in reproductive management. However, the least adopted technologies in this group of farmers were using male breeds (T23), female breeds (T25) and genetically tested bulls (T27), with an adoption rate of $37.34 \%, 22.45 \%$ and $20.10 \%$, respectively.

\subsection{Benchmarking Analysis}

The benchmarking of influencer farmers by organization type is shown in Table 4, both in its centrality network measures, technological level, and structural characteristics. The Farmer influencer (f_623), was affiliated to the SPR, with an adoption rate of 100\% and the highest betweenness value in the network (16.71). Besides, high values of degree, eigenvector, betweenness and low levels of constraint favoured high levels of social capital. This farmer presented a similar productive structure (size, productive animals, surface, etc.) to the rest of the GGAVATT and SPR leaders, although was different in its productive orientation and in the use of resources. Its strategy was diversified, allocating part of the production to the sale of milk, meat, and cheese. According to Guiomar et al. [3,5,11], De-Pablos-Heredero et al. [3,5,11], and Granados-Rivera et al. [3,5,11], high technological 
adoption rates are associated with a diversified productive strategy. Likewise, they obtained high productivity by lactation $(1820 \mathrm{l} / \mathrm{cow})$, high stocking rate $(40 \mathrm{UA} / \mathrm{ha})$, and generated four direct employments. Despite previous studies that have reported that farm size is the main factor in determining the technology adoption level $[57,59,60]$ and that relation exists amongst the farm's size, productivity, and efficiency [61], within the group of small-scale farmers, the producers can also be efficient $[5,29,62]$. These results highlighted that the differences in technology adoption were given by the network measures and the productive strategies developed. Furthermore, through benchmarking analysis, three farmers' profiles were identified.

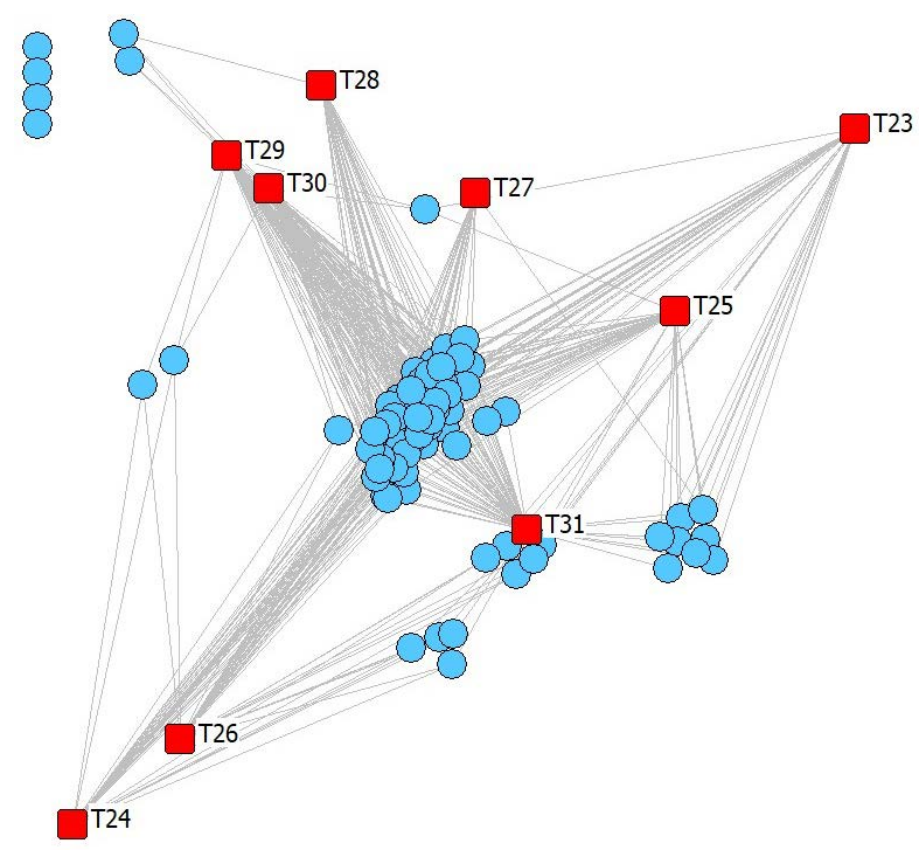

Figure 3. Two-mode network visualization of farmers and technologies. Technologies: T23. Using male breeds, T24. Using male crosses, T25. Using female breeds, T26. Using female crosses, T27. Use of genetically tested bulls, T28. Calves selection criteria, T29. Female selection criteria, T30. Sire selection criteria, T31. Crossbred system; Farmers.

High technology level. The GGAVATT and SPR farmers were technologically similar (f_374, F_1165), showed close positions in the network (Figure 2) and very similar centrality network measures (Table 4). The GGAVATT farmer received public technical assistance. On the contrary, the advice in SPR was private. Their productive orientation was strongly different. The GGAVAAT farmer was specialized in milk, while SPR farmer in milk-meat. In addition, the SPR farmer showed high productivity ( $1714 \mathrm{l} /$ cow and 10 calves sold). In the GGAVATT there has been a generational renewal with younger producers and only one employee, while in SPR, the farmer was older, with three people economically dependent on the activity. Similar results were reported by Granados-Rivera et al. [10] and Díaz et al. [59].

Medium technology level. The leaders of other producer private organizations had much more limited advice $[1,8,9]$. Cooperative, producers' organization and non-affiliation farmers showed a medium technological level (78\%) and similar network centrality values among them. The leading producers of each organization of this group showed low technological adoption and centrality values, a low diversification degree, dairy specialization, low calf production and no cheese production $[2,29,31]$. However, the number of people economically dependent on the activity and the number of workers were high. Non-affiliation farmers (f_183) were close to other organizations (Figure 2) and showed similar technological and centrality network values. 
Low technological level. The farmer affiliated to non-productive organizations (f_76), showed low network centrality and technology values (56\%). This is due to the fact that this farmer was disconnected to the network. His strategy was based on milk and cheese production, with three workers $[6,9,29,59]$.

The benchmarking analysis showed that belonging to a certain organization favours the technology adoption rate, although the degree of connectivity with other producers is more important. Being connected to technological leaders and farmers affiliated to different organizations with different social capital positively affects the technology adoption rate since this diversity is a source of information, knowledge, and resources. This research makes a significant contribution to advancing the understanding of the low technology adoption rate in the area of reproductive management in livestock systems, as technology is a strategic tool for development and increasing the competitiveness and viability of the farms $[5,19,63]$, and contributions to the field will foster development that allows one to identify viable technologies, the sequence of adoption, the mode of dissemination and the technological leaders [8,28]. These findings agree with Zacharakis et al. [64], who suggested that networks are most effective when they are diverse, inclusive, flexible, horizontal (linking those of similar status) and vertical, linking those who have resources not available within the community. These results also match those found by Dhehibi et al. [65], who studied the agricultural technology transfer preferences of smallholder farmers in Tunisia and found that farmer-to-farmer interactions were perceived as the most effective agricultural extension methods. The author also points out that the know-how influenced the adoption level. In the context of innovation dissemination, this is related to the social learning theory which states that people learn with and from others by example or through observation [66].

Similarly, Zarazúa et al. [35] applied the SNA approach to assess social capital indicators in two groups of corn producers in Michoacán and found a strong relationship between the enhancement of technological innovation and the links established by farmers with actors involved in livestock activities. In this case, the farmers belonging to the most open network configuration presented better productive outcomes. These results were in line with those of Espejel-García et al. [60] where, in their study of the interaction patterns in Mexico rural innovation system, they found that there were agents who act as intermediaries of innovation with the ability to articulate the innovation system, link the actors and bring innovation to the end user. The author concluded that intermediaries with greater links defined the sources and types of innovation and activate interaction patterns between the several actors of the system.

On the other hand, Gholifar et al. [67] used the SNA approach to study sustainable aquaculture systems through an institutional collaboration network at Alborz Watershed in Iran and found that organizations can play a key role in the distribution of information, knowledge, and intersectoral cooperation among social agents, and pointed out that government agencies have more power and centrality in comparison to nongovernmental organizations, indicating a lack of co-management in the field. However, these results differ from Kleinnijenhuis et al. [68] who measured social influence in networks of practice and found that the members in the network who communicate about informal practice, and know who knows what, exert more social influence than others, suggesting that members' social influence is rooted in their utilitarian value for others, and not in their organizational embeddedness.

In summary, the presented findings seem to be consistent with previous research on agricultural technology adoption [38,69-73], which found that farmers' decisions to innovate are not based only on economic performance, but also in the context of social interactions among themselves and with agents that promote change.

The main limitation of this methodology lies in the sample definition. Future studies on the current topic are therefore recommended, using other analyses proposed in the literature to further investigate the nature of network data in the theoretical framework under study. 


\section{Conclusions}

This research delved into the factors to explain the low technology adoption rate in the very small dual-purpose cattle farms in the Mexican tropics, employing the descriptive measure of social network analysis approach to examine its structure. The sample consisted of 383 farmers and nine reproductive management technologies are measured. The results showed that the farmer's position in the network has a significant impact on their access to information as a productive resource. On the contrary, the farmers farthest from the central network position showed the lowest levels of betweenness value and high rates of constraint.

Using various centrality network measures, we identified three important factors within the agricultural innovation processes: the central farmers, the core technologies, and their adoption patterns. We found that there are elementary technologies widely adopted by most farmers and complementary technologies that tend to be jointly adopted; the adoption of one affects the adoption of the other.

The social network analysis approach seemed to be a valuable tool in improving decision-making processes within agricultural extension and training programmes, since it allowed one to analyse patterns of relationships between farmers and had a graph visualization of the network, showing the key agents with high potential to spread innovations. SNA was a useful methodological perspective of analysis to map knowledge networks within smallholder farmer communities that should be undertaken at the planning stage of programme development to build community social capital.

Author Contributions: Conceptualization and methodology, all authors; formal analysis, software, data curation, data processing, O.V.-M., J.R. and M.P.V.; statistical and network analysis, O.V.-M. and A.G.; validation and investigation, A.G., and C.D.-P.-H.; supervision, project administration, A.G., J.R., and C.D.-P.-H.; data acquisition, J.R. and O.V.-M. All authors have been involved in developing, writing, commenting, editing, and reviewing the manuscript. All authors have read and agreed to the published version of the manuscript.

Funding: This research received no external funding.

Institutional Review Board Statement: Not applicable.

Informed Consent Statement: Not applicable.

Data Availability Statement: This is not applicable as the data are not in any data repository of public access, however, if the editorial committee needs access, we will happily provide them. Please use this email: pa1gamaa@uco.es.

Acknowledgments: We want to thank the National Institute of Forestry, Crops, and Livestock Research (INIFAP-México) for the financial support to the Research Project SIGI, Number 21541832011, to James Cook, University of Maine at Augusta, for his technical support in the use of UCINET, and to OpenInnova High Performance Group at Rey Juan Carlos University and ECONGEST AGR267 Group at Córdoba University for the support to this research.

Conflicts of Interest: The authors declare no conflict of interest.

\section{References}

1. Bettencourt, E.M.V.; Tilman, M.; Narciso, V.; Carvalho, M.L.d.S.; Henriques, P.D.d.S. The livestock roles in the wellbeing of rural communities of Timor-Leste. Rev. Econ. Sociol. Rural 2015, 53, 63-80. [CrossRef]

2. Steinfeld, H.; Mack, S. Livestock development strategies. World Anim. Rev. 1995, 84, 18-24.

3. Guiomar, N.; Godinho, S.; Pinto-Correia, T.; Almeida, M.; Bartolini, F.; Bezak, P.; Biro, M.; Bjørkhaug, H.; Bojnec, ̌̌.; Brunori, G. Typology and distribution of small farms in Europe: Towards a better picture. Land Use Policy 2018, 75, 784-798. [CrossRef]

4. HLPE. Investing in Smallholder Agriculture for Food Security; A report by the High Level Panel of Experts on Food Security and Nutrition of the Committee on World Food Security; Food and Agriculture Organization of the United Nations (FAO): Rome, Italy, 2013; p. 111.

5. De-Pablos-Heredero, C.; Montes-Botella, J.L.; Garcia, A. Impact of technological innovation on performance in dairy sheep farms in Spain. J. Agric. Sci. Tech-Iran 2020, 22, 597-610. 
6. Rojo-Rubio, R.; Vazquez-Armijo, J.F.; Perez-Hernandez, P.; Mendoza-Martinez, G.D.; Salem, A.Z.M.; Albarran-Portillo, B.; Gonzalez-Reyna, A.; Hernandez-Martinez, J.; Rebollar-Rebollar, S.; Cardoso-Jimenez, D.A.; et al. Dual purpose cattle production in Mexico. Trop. Anim. Health Pro. 2009, 41, 715-721. [CrossRef]

7. Morantes, M.; Dios-Palomares, R.; Urdaneta, F.; Rivas, J.; García-Martínez, A. Eficiencia técnica en sistemas de producción con bovinos de doble propósito. Arch. de Zootec. 2020, 69, 190-195. [CrossRef]

8. Rangel, J.; Espinosa, J.A.; de Pablos-Heredero, C.; Barba, C.; Velez, A.; Rivas, J.; Garcia, A. Adoption of innovations and organizational practices in management, animal feeding and reproduction in dual-purpose bovine of small farms in Mexico. Rev. Cient-Fac. Cien V. 2017, 27, 44-55.

9. Garcia-Martinez, A.; Rivas-Rangel, J.; Rangel-Quintos, J.; Espinosa, J.A.; Barba, C.; De-Pablos-Heredero, C. A Methodological approach to evaluate livestock innovations on small-scale farms in developing countries. Future Internet 2016, 8, 25. [CrossRef]

10. Granados-Rivera, L.D.; Quiroz-Valiente, J.; Maldonado-Jáquez, J.A.; Granados-Zurita, L.; Díaz-Rivera, P.; Oliva-Hernández, J. Caracterización y tipificación del sistema doble propósito en la ganadería bovina del distrito de desarrollo rural 151, Tabasco, México. Acta Universitaria 2018, 28, 47-57. [CrossRef]

11. Rangel, J.; Perea, J.; De-Pablos-Heredero, C.; Espinosa-García, J.A.; Mujica, P.T.; Feijoo, M.; Barba, C.; García, A. Structural and technological characterization of tropical smallholder farms of dual-purpose cattle in Mexico. Animals 2020, 10, 86. [CrossRef] [PubMed]

12. Morantes, M.; Olarte, A.; Palomares, R.D.; Colmenares, O.; Rivas, J.; Paparamborda, I.; Blanca, J.; Martínez, A.G. Caracterización tecnológica de los sistemas de producción doble propósito con vacunos en el trópico: I. Identificación e implementación de tecnologías. Rev. Cient-Fac. Cien. V. 2019, 60, 37-45.

13. Rangel, J.; Rivas, J.; Torres, Y.; Perea, J.; De-Pablos-Heredero, C.; Barba, C.; García, A. Effect of flock size and ecological area in the technological level of dual-purpose cattle system from Ecuadorian Tropics. Rev. Cient-Fac. Cien. V. 2016, 26, $164-172$.

14. Espinosa-García, J.A.; Quiroz-Valiente, J.; Moctezuma-Lopez, G.; Oliva-Hernandez, J.; Granados-Zurita, L.; Berumen-Alatorre, A.C. Technological prospection and strategies for innovation in production of sheep in Tabasco, México. Rev. Cient-Fac. Cien. V. 2015, 25, 107-115.

15. Aguirre-López, J.M.; Díaz-José, J.; Chaloupková, P.; Guevara-Hernández, F. Unraveling innovation networks in conservation agriculture using social network analysis. In Challenges in Social Network Research; Springer: Milano, Italy, 2020; pp. 133-148.

16. Taramuel, J.; Barrios, D.; Cerón-Muñoz, M. Adopción tecnológica en sistemas de producción de leche del resguardo indígena de Cumbal en el departamento de Nariño, Colombia. Sistema 2019, 4, 1-44.

17. Bandiera, O.; Rasul, I. Social networks and technology adoption in northern Mozambique. Econ. J. 2006, 116, 869-902. [CrossRef]

18. Abdulai, A.; Huffman, W.E. The diffusion of new agricultural technologies: The case of crossbred-cow technology in Tanzania. Am. J. Agric. Econ. 2005, 87, 645-659. [CrossRef]

19. Bastanchury-López, M.T.; De-Pablos-Heredero, C.; Montes-Botella, J.L.; Martín-Romo-Romero, S.; García, A. Impact of dynamic capabilities on performance in dairy sheep farms in Spain. Sustainability 2020, 12, 3368. [CrossRef]

20. Mashavave, T.; Mapfumo, P.; Mtambanengwe, F.; Gwandu, T.; Siziba, S. Interaction patterns determining improved information and knowledge sharing among smallholder farmers. Afr. J. Agric. Resour. Econ. 2013, 8, 1-12.

21. Wasserman, S.; Faust, K. Social Network Analysis: Methods and Applications; Cambridge University Press: Cambridge, UK, $1994 ;$ Volume 8.

22. Wasserman, S.; Faust, K. Análisis de Redes Sociales. Métodos y Aplicaciones; CIS: Hong Kong, China, 2013; Volume 10.

23. Borgatti, S.P.; Everett, M.G. Notions of position in social network analysis. Sociol. Methodol. 1992, 22, 1-35. [CrossRef]

24. Borgatti, S.P.; Everett, M.G. A graph-theoretic perspective on centrality. Soc. Netw. 2006, 28, 466-484. [CrossRef]

25. Borgatti, S.P.; Mehra, A.; Brass, D.J.; Labianca, G. Network Analysis in the Social Sciences. Science 2009, 323, 892-895. [CrossRef]

26. Borgatti, S.P.; Halgin, D.S. On Network Theory. Organ. Sci. 2011, 22, 1168-1181. [CrossRef]

27. Kahan, D. Farm Business Analysis Using Benchmarking; FAO: Rome, Italy, 2013.

28. Villarroel-Molina, O.; Barba, C.; García, A.; Rangel, J. Use of social networks to explore smallholder's adoption of technologies in dual purpose farms. ESIC Mark. 2019, 50, 233-257.

29. Rangel, J.; Espinosa, J.A.; de Pablos-Heredero, C.; Rivas, J.; Perea, J.; Angon, E.; Garcia-Martinez, A. Is the increase of scale in the tropics a pathway to smallholders? Dimension and ecological zone effect on the mixed crop-livestock farms. Span J. Agric. Res. 2017, 15, 10. [CrossRef]

30. Torres, Y.; Garcia, A.; Rivas, J.; Perea, J.; Angon, E.; De Pablos-Heredero, C. Socioeconomic and productive characterization of dual-purpose farms oriented to milk production in a tropical region of Ecuador. The case of the province of Manabí. Rev. Cient-Fac. Cien. V. 2015, 25, 330-337.

31. Rivas, J.; Manuel Perea, J.; De-Pablos-Heredero, C.; Morantes, M.; Angon, E.; Barba, C.; García, A. Role of technological innovation in livestock breeding programmes: A case of cereal-sheep system. Ital. J. Anim. Sci. 2019, 18, 1049-1057. [CrossRef]

32. Lin, N. Building a network theory of social capital. Connections 1999, 22, 28-51.

33. Borgatti, S.P.; Jones, C.; Everett, M.G. Network measures of social capital. Connections 1998, 21, 27-36.

34. Rodríguez-Modroño, P. Análisis relacional del capital social y el desarrollo de los sistemas productivos regionales. Redes 2012, 23, 261-290. [CrossRef]

35. Zarazúa, J.-A.; Almaguer-Vargas, G.; Rendón-Medel, R. Capital social. Caso red de innovación de maíz en Zamora, Michoacán, México. Cuad. Desarro. Rural 2012, 9, 105-124. 
36. Parker, A.; Halgin, D.S.; Borgatti, S.P. Dynamics of social capital: Effects of performance feedback on network change. Organ. Stud. 2016, 37, 375-397. [CrossRef]

37. Saint Ville, A.S.; Hickey, G.M.; Locher, U.; Phillip, L.E. Exploring the role of social capital in influencing knowledge flows and innovation in smallholder farming communities in the Caribbean. Food Secur. 2016, 8, 535-549. [CrossRef]

38. Hauser, C.; Tappeiner, G.; Walde, J. The learning region: The impact of social capital and weak ties on innovation. Reg. Stud. 2007, 41, 75-88. [CrossRef]

39. Burt, R.S. The network structure of social capital. Res. Organ. Behav. 2000, 22, 345-423. [CrossRef]

40. Rutten, R.; Westlund, H.; Boekema, F. The spatial dimension of social capital. Eur. Plan. Stud. 2010, 18, 863-871. [CrossRef]

41. García-Valdecasas, J.I. Una definición estructural de capital social. Redes 2011, 20, 132-160. [CrossRef]

42. Webb, C. Measuring social capital and knowledge networks. J. Knowl. Manag. 2008, 12, 65-78. [CrossRef]

43. Burt, R.S. Structural Holes: The Social Structure of Competition; Harvard University Press: Cambridge, MA, USA, 2009.

44. Granovetter, M. A Theoretical Agenda for Economic Sociology; CDL: Singapore, 2000.

45. Norbutas, L.; Corten, R. Network structure and economic prosperity in municipalities: A large-scale test of social capital theory using social media data. Soc. Netw. 2018, 52, 120-134. [CrossRef]

46. Borgatti, S.P. Centrality and network flow. Soc. Netw. 2005, 27, 55-71. [CrossRef]

47. Bonacich, P.; Lloyd, P. Eigenvector-like measures of centrality for asymmetric relations. Soc. Netw. 2001, 23, 191-201. [CrossRef]

48. Bonacich, P. Measures of Centrality. In The Blackwell Encyclopedia of Sociology; Blackwell Pub.: Malden, MA, USA, $2018 ;$ pp. 1-2.

49. Bonacich, P. Power and centrality: A family of measures. Am. J. Sociol. 1987, 92, 1170-1182. [CrossRef]

50. Opsahl, T.; Agneessens, F.; Skvoretz, J. Node centrality in weighted networks: Generalizing degree and shortest paths. Soc. Netw. 2010, 32, 245-251. [CrossRef]

51. Freeman, L.C. Centrality in social networks conceptual clarification. Soc. Netw. 1978, 1, 215-239. [CrossRef]

52. Borgatti, S.P.; Everett, M.G. Network analysis of 2-mode data. Soc. Netw. 1997, 19, 243-270. [CrossRef]

53. Everett, M.G.; Borgatti, S.P. The dual-projection approach for two-mode networks. Soc. Netw. 2013, 35, 204-210. [CrossRef]

54. Park, M.; Lawlor, M.C.; Solomon, O.; Valente, T.W. Understanding connectivity: The parallax and disruptive-productive effects of mixed methods social network analysis in occupational science. J. Occup. Sci 2020, 1-21. [CrossRef]

55. Borgatti, S.P.; Everett, M.G.; Johnson, J.C. Analyzing Social Networks., 1st ed.; Sage: London, UK, 2018 ; pp. 1-296.

56. Hanneman, R.A.; Riddle, M. Introduction to Social Network Methods; University of California: Oakland, CA, USA, 2005.

57. Ponce-Méndez, F.; Álvarez-Bernal, D.; Ceja-Torres, L.F. Model GGAVATT and networks of innovation in the dairy basin in the Cienega of Chapala, Michoacán. Mexicana Cienc. Agric. 2016, 7, 545-558.

58. Borgatti, S.P.; Everett, M.G.; Freeman, L.C. Ucinet for Windows: Software for Social Network Analysis; Analytic Technologies: Harvard, MA, USA, 2002.

59. Díaz, P.; Oros, V.; Martinez, J.; Torres, G.; Vilaboa-Arroniz, J. Dynamics of development of dual purpose cattle in Las Choapas, Veracruz, Mexico. Trop. Subtrop. Agroecosyst. 2010, 14, 191-199.

60. Espejel-García, A.; Cuevas-Reyes, V.; Muñoz-Rodríguez, M.; Barrera-Rodríguez, A.; Cervantes-Escoto, F.; Sosa-Montes, M. Sistema regional de innovación y desarrollo rural territorial; pequeños productores de leche del valle del Mezquital, Estado de Hidalgo, México. Span. J. Rural Dev. 2014, 5, 1-14. [CrossRef]

61. Rada, N.E.; Fuglie, K.O. New perspectives on farm size and productivity. Food Policy 2019, 84, 147-152. [CrossRef]

62. Gautam, M.; Ahmed, M. Too small to be beautiful? The farm size and productivity relationship in Bangladesh. Food Policy 2019, 84, 165-175. [CrossRef]

63. Rivas, J.; Perea, J.M.; De-Pablos-Heredero, C.; Angon, E.; Barba, C.; García, A. Canonical correlation of technological innovation and performance in sheep's dairy farms: Selection of a set of indicators. Agric. Syst. 2019, 176, 1-8. [CrossRef]

64. Zacharakis, J.; Flora, J. Riverside: A case study of social capital and cultural reproduction and their relationship to leadership development. Adult Educ. Q. 2005, 55, 288-307. [CrossRef]

65. Dhehibi, B.; Rudiger, U.; Moyo, H.P.; Dhraief, M.Z. Agricultural technology transfer preferences of smallholder farmers in Tunisia's Arid Regions. Sustainability 2020, 12, 421. [CrossRef]

66. Akers, R.L.; Jennings, W.G. Social learning theory. Handb. Criminol. Theory 2015, 4, 230-240.

67. Gholifar, E.; Abbasi, E.; Rezaei, A. Sustainable aquaculture system: Institutional scientific collaboration network in Alborz Watershed, Iran. J. Agric. Sci. Tech-Iran 2019, 21, 277-293.

68. Kleinnijenhuis, J.; van den Hooff, B.; Utz, S.; Vermeulen, I.; Huysman, M. Social influence in networks of practice: An analysis of organizational communication content. Commun. Res. 2011, 38, 587-612. [CrossRef]

69. Díaz-José, J.; Rendón-Medel, R.; Aguilar-Ávila, J.; Muñoz-Rodríguez, M. Dynamic analysis of networks in the diffusion of agricultural innovations. Rev. Mex. Cienc. Agric. 2013, 4, 1095-1102.

70. Deroian, F. Formation of social networks and diffusion of innovations. Res. Policy 2002, 31, 835-846. [CrossRef]

71. Weiss, K.; Hamann, M.; Kinney, M.; Marsh, H. Knowledge exchange and policy influence in a marine resource governance network. Glob. Environ. Chang. 2012, 22, 178-188. [CrossRef]

72. Hernández Guevara, J.E. Análisis de la Red de Información y Adopción de Innovaciones en Productores Lecheros en la Provincia de Melipilla. Master's Thesis, Veterinarias Universidad de Chile, Santiago, Chile, 2015.

73. Vishnu, S.; Gupta, J.; Subash, S.P. Social network structures among the livestock farmers vis a vis calcium supplement technology. Inf. Process. Agric. 2019, 6, 170-182. [CrossRef] 